\title{
Massilia jejuensis sp. nov. and Naxibacter suwonensis sp. nov., isolated from air samples
}

\author{
Correspondence \\ Soon-Wo Kwon \\ swkwon@rda.go.kr
}

\author{
Hang-Yeon Weon, ${ }^{1}$ Seung-Hee Yoo, ${ }^{1}$ Soo-Jin Kim, ${ }^{1}$ Yi-Seul Kim, ${ }^{1}$ \\ Rangasamy Anandham ${ }^{2}$ and Soon-Wo Kwon ${ }^{1}$
}

\author{
${ }^{1}$ Korean Agricultural Culture Collection (KACC), National Agrobiodiversity Center, National \\ Academy of Agricultural Science, Rural Development Administration, Suwon 441-707, Republic of \\ Korea \\ ${ }^{2}$ Agricultural Microbiology, Department of Agricultural Microbiology, Agricultural College and \\ Research Institute, Madurai, India
}

Two Gram-negative, motile, rod-shaped bacteria (strains $5317 \mathrm{~J}-18^{\top}$ and $5414 \mathrm{~S}-25^{\top}$ ) were isolated from air samples collected in the Jeju Island and Suwon region of Korea, respectively. Phylogenetically, strain $5317 \mathrm{~J}-18^{\top}$ was grouped with the genus Massilia with Massilia brevitalea byr23-80 $0^{\top}$ as the closest relative ( $98.8 \%$ sequence similarity). Strain $5414 \mathrm{~S}-25^{\top}$ was affiliated with the genus Naxibacter with Naxibacter haematophilus CCUG $38318^{\top}$ as the closest relative (98.8\% sequence similarity). The mean DNA-DNA relatedness values between strain $5317 \mathrm{~J}-18^{\top}$ and M. brevitalea DSM $18925^{\top}$ and Massilia aurea DSM $18055^{\top}$ were 43 and $36 \%$, respectively. The mean DNA-DNA hybridization values between strain $5414 \mathrm{~S}-25^{\top}$ and $N$. haematophilus KACC $13771^{\top}$, M. brevitalea DSM $18925^{\top}$, Massilia timonae DSM $16850^{\top}$, Naxibacter varians KACC $13770^{\top}$, M. aurea DSM $18055^{\top}$, Massilia lutea DSM $17473^{\top}$ and Massilia albidiflava DSM $17472^{\top}$ ranged from 33 to $42 \%$. Both novel strains had ubiquinone Q-8 as the predominant isoprenoid quinone and summed feature 3 (comprising iso- $\mathrm{C}_{15: 0} 2-\mathrm{OH}$ and/or $\mathrm{C}_{16: 1} \omega 7 \mathrm{c}$ ) and $\mathrm{C}_{16: 0}$ as the major fatty acids. Both strains also showed similar polar lipid profiles with phosphatidylethanolamine, phosphatidylglycerol and diphosphatidylglycerol as the major polar lipids. The DNA G $+\mathrm{C}$ contents of strains $5317 \mathrm{~J}-18^{\top}$ and $5414 \mathrm{~S}-25^{\top}$ were 66.1 and $67.8 \%$, respectively. On the basis of their phenotypic, chemotaxonomic and genotypic characteristics, the new strains represent novel species in the genera Massilia and Naxibacter. Strain $5317 \mathrm{~J}-18^{\top}$ $\left(=\right.$ KACC $12634^{\top}=$ DSM $\left.21309^{\top}\right)$ is proposed as the type strain of Massilia jejuensis sp. nov. and strain $5414 \mathrm{~S}-25^{\top}\left(=\right.$ KACC $\left.12635^{\top}=\mathrm{DSM} 21311^{\top}\right)$ is proposed as the type strain of Naxibacter suwonensis sp. nov.
La Scola et al. (1998) proposed the genus Massilia for an isolate from the blood of an immunocompromised patient with cerebellar lesions. Members of the genus are aerobic, Gram-negative, motile, non-spore-forming rods to shortrods and are catalase-positive. Chemotaxonomically, members of this genus contain summed feature 3 (comprising iso- $\mathrm{C}_{15: 0} 2-\mathrm{OH}$ and/or $\left.\mathrm{C}_{16: 1} \omega 7 c\right)$ and $\mathrm{C}_{16: 0}$ as the major fatty acids and Q-8 as the predominant isoprenoid quinone

Abbreviations: NJ, neighbour-joining; ML, maximum-likelihood; MP, maximum-parsimony.

The GenBank/EMBL/DDBJ accession numbers for the $16 \mathrm{~S}$ rRNA gene sequences of strains $5317 \mathrm{~J}-18^{\top}$ and $5414 \mathrm{~S}-25^{\top}$ are FJ969486 and FJ969487, respectively.

Additional phylogenetic trees based on analysis of 165 rRNA gene sequences using the maximum-likelihood and maximum-parsimony algorithms and the polar lipid profile are available as supplementary figures with the online version of this paper. and show relatively high $\mathrm{G}+\mathrm{C}$ contents (62-68.9 mol\%). To date, this genus comprises ten species with validly published names, including the type species Massilia timonae (La Scola et al., 1998; Gallego et al., 2006; Zhang et al., 2006; Weon et al., 2008, 2009; Zul et al., 2008). The genus Naxibacter was originally erected to represent one soil isolate, Naxibacter alkalitolerans (Xu et al., 2005). Later, two additional species, Naxibacter varians and Naxibacter haematophilus, were described and the genus description was emended (Kämpfer et al., 2008). The genus Naxibacter is closely related to the genus Massilia. This paper describes the isolation and characterization of two novel strains collected from air samples.

Strains $5317 \mathrm{~J}-18^{\mathrm{T}}$ and $5414 \mathrm{~S}-25^{\mathrm{T}}$ were isolated from air samples collected from Jeju Island and the Suwon region, Korea, respectively. The air samples were collected by using an MAS-100 air sampler (single-stage multiple-hole impactor; Merck) that contained Petri dishes with R2A 
medium (BBL) supplemented with cycloheximide (Sigma) at $200 \mu \mathrm{g} \mathrm{ml}^{-1}$.

Tests to determine Gram staining, catalase and oxidase activities, and hydrolysis of casein, DNA, hypoxanthine, starch, Tween 80 and xanthine were performed according to the methods of Smibert \& Krieg (1994). Cellular morphology was determined by light microscopy (Axio; Zeiss) and transmission electron microscopy (TEM) using 1-day-old cells. For TEM observations, the cells were negatively stained with $0.5 \%(\mathrm{w} / \mathrm{v})$ uranyl acetate and examined with a model $912 \mathrm{AB}$ (LEO) microscope. The temperature range $\left(4-50{ }^{\circ} \mathrm{C}\right)$ and $\mathrm{pH}$ range $(4-10$ at intervals of $1 \mathrm{pH}$ unit) for growth and the requirement for $\mathrm{NaCl}[0,1,2,3,5$ and $7 \%(\mathrm{w} / \mathrm{v})]$ were determined using R2A medium. Hydrolysis of carboxymethylcellulose $(0.1 \%, \mathrm{w} / \mathrm{v})$, chitin from crab shells $(1 \%, \mathrm{w} / \mathrm{v})$, pectin $(1 \%, \mathrm{w} / \mathrm{v})$ and tyrosine $(0.5 \%, \mathrm{w} / \mathrm{v})$ were also tested. The commercially available API $20 \mathrm{NE}$ and API ID $32 \mathrm{GN}$ test kits (bioMérieux) were used to determine the biochemical properties, utilization of carbohydrates and enzymic activities of the novel strains according to the manufacturer's instructions. The API ZYM tests were read after $4 \mathrm{~h}$ incubation at $37^{\circ} \mathrm{C}$, the other API tests were read after $72 \mathrm{~h}$ at $28{ }^{\circ} \mathrm{C}$. Strains $5317 \mathrm{~J}-18^{\mathrm{T}}$ and $5414 \mathrm{~S}-25^{\mathrm{T}}$ could be differentiated from members of the genera Massilia and Naxibacter on the basis of the results of assimilation tests and other physiological properties. Some of these results are given in the species description; Table 1 shows a comparison of the characteristics of strains $5317 \mathrm{~J}-18^{\mathrm{T}}$ and $5414 \mathrm{~S}-25^{\mathrm{T}}$ and closely related strains.

Chromosomal DNA was extracted and purified according to the method of Ausubel et al. (1987), except that the lysates were extracted twice with chloroform to remove residual phenol. The 16S rRNA genes were amplified by PCR from chromosomal DNA using two universal primers for bacteria (Weisburg et al., 1991). The PCR products were purified and sequenced using the BigDye Terminator Cycle Sequencing Ready Reaction kit (Applied Biosystems) according to the manufacturer's instructions. The $16 \mathrm{~S}$ rRNA gene sequences from the novel isolates and related taxa (obtained from the NCBI database) were aligned using the CLUSTAL $\mathrm{W}$ multiple sequence alignment program (Thompson et al., 1994). Sequence similarities were calculated using the EzTaxon server (http://www.eztaxon. org/; Chun et al., 2007). Phylogenetic trees were constructed with the neighbour-joining (NJ; Saitou \& Nei, 1987), maximum-parsimony (MP; Kluge \& Farris, 1969) and maximum-likelihood (ML; Felsenstein, 1981) methods using the MEGA3 program (Kumar et al., 2004), with bootstrap values based on 1000 replications (Felsenstein, 1985). Phylogenetic trees (Fig. 1 and Supplementary Figs S1 and S2 in IJSEM Online) indicated that strain 5317J-18 was phylogenetically affiliated with Massilia brevitalea byr23-80 ${ }^{\mathrm{T}}$ with high bootstrap values $(99,98$ and $97 \%$ by the NJ, ML and MP methods, respectively) and strain $5414 \mathrm{~S}-25^{\mathrm{T}}$ grouped with the members of the genus Naxibacter (77, 66 and $65 \%$ by the NJ, ML and MP methods, respectively). Strain $5317 \mathrm{~J}-18^{\mathrm{T}}$ showed the highest sequence similarities with $M$. brevitalea byr $23-80^{\mathrm{T}}(98.8 \%)$ and Massilia aurea $\mathrm{AP}^{\mathrm{T}}{ }^{\mathrm{T}}(97.9 \%)$. Strain $5414 \mathrm{~S}-25^{\mathrm{T}}$ revealed high gene sequence similarities with $N$. haematophilus CCUG $38318^{\mathrm{T}}(98.8 \%)$, M. brevitalea byr $23-80^{\mathrm{T}}$ (98.2\%), M. timonae CIP $105350^{\mathrm{T}}(97.6 \%)$, N. varians CCUG $35299^{\mathrm{T}}(97.5 \%)$, M. aurea AP13 ${ }^{\mathrm{T}}$ (97.3\%), Massilia lutea $101^{\mathrm{T}}(97.2 \%)$ and Massilia albidiflava $45^{\mathrm{T}}(97.0 \%)$.

For the assessment of DNA-DNA relatedness values, DNA-DNA hybridization was carried out according to the method of Seldin \& Dubnau (1985). The mean DNADNA relatedness values between strain $5317 \mathrm{~J}-18^{\mathrm{T}}$ and $M$. brevitalea DSM $18925^{\mathrm{T}}$ and M. aurea DSM $18055^{\mathrm{T}}$ were 43 and $36 \%$, respectively. The mean DNA-DNA hybridization values between strain $5414 \mathrm{~S}-25^{\mathrm{T}}$ and $N$. haematophilus KACC $13771^{\mathrm{T}}$, M. brevitalea DSM $18925^{\mathrm{T}}$, M. timonae DSM $16850^{\mathrm{T}}, N$. varians KACC $13770^{\mathrm{T}}, M$. aurea DSM $18055^{\mathrm{T}}$, M. lutea DSM $17473^{\mathrm{T}}$ and $M$. albidiflava DSM $17472^{\mathrm{T}}$ were $42,42,39,38,34,33$ and $33 \%$, respectively. These DNA-DNA relatedness values of less than $70 \%$ (Wayne et al., 1987) indicated that the two novel isolates represent two distinct genospecies.

Cell biomass for the analysis of cell-wall and isoprenoid quinones, polar lipids and fatty acids was obtained from cells grown in $\mathrm{R} 2 \mathrm{~A}$ medium at $28{ }^{\circ} \mathrm{C}$ for 2 days. Isoprenoid quinones and polar lipids were obtained using the methods of Minnikin et al. (1984). The fatty acids were analysed according to the standard protocol of the Sherlock Microbial Identification System (Sasser, 1990). The DNA $\mathrm{G}+\mathrm{C}$ content was determined using an HPLC method (Mesbah et al., 1989). The predominant isoprenoid quinone for strains $5317 \mathrm{~J}-18^{\mathrm{T}}$ and $5414 \mathrm{~S}-25^{\mathrm{T}}$ was ubiquinone Q-8 with a trace amount of Q-7. Strains $5317 \mathrm{~J}-18^{\mathrm{T}}$, $5414 \mathrm{~S}-25^{\mathrm{T}}$ and the two reference strains, $M$. brevitalea DSM $18925^{\mathrm{T}}$ and N. alkalitolerans KACC $12188^{\mathrm{T}}$, had similar polar lipid patterns with the predominant polar lipids of phosphatidylethanolamine, phosphatidylglycerol and diphosphatidylglycerol (see Supplementary Fig. S3 in IJSEM Online). The fatty acid contents of strains $5317 \mathrm{~J}-18^{\mathrm{T}}$ and $5414 \mathrm{~S}-25^{\mathrm{T}}$ both contained summed feature 3 $\left(\mathrm{C}_{16: 1} \omega 7 c\right.$ and/or iso- $\mathrm{C}_{15: 0} 2-\mathrm{OH} ; 49$ and $45.8 \%$, respectively) and $\mathrm{C}_{16: 0}$ (22.5 and $28.8 \%$, respectively) as the major components and moderate amounts of $\mathrm{C}_{18: 1} \omega 7 \mathrm{c}$ (12.1 and 7.8\%, respectively), $\mathrm{C}_{10: 0} 3-\mathrm{OH}$ (6.1 and 5.4\%, respectively) and $\mathrm{C}_{12: 0}(5.9$ and $4.4 \%$, respectively) (Table 2). The same fatty acid patterns were also found for other species of the genera Massilia and Naxibacter. The DNA G + C contents of strains $5317 \mathrm{~J}-18^{\mathrm{T}}$ and $5414 \mathrm{~S}-25^{\mathrm{T}}$ were 66.1 and $67.8 \%$, respectively.

The genus Naxibacter was originally reported by $\mathrm{Xu}$ et al. (2005) on the basis of several phenotypic properties that were different from those of closely related genera. In particular, the genera Massilia and Naxibacter could be distinguished on the basis of starch hydrolysis, urease production, oxidase production, utilization of sole carbon 
Table 1. Differential properties of species of the genera Massilia and Naxibacter

Strains: $1,5317 \mathrm{~J}-18^{\mathrm{T}}$ (data from this study); 2, 5414S-25 ${ }^{\mathrm{T}}$ (data from this study); 3, M. aerilata KACC $12505^{\mathrm{T}}$ (Weon et al., 2008); 4, M. albidiflava DSM $17472^{\mathrm{T}}$ (Weon et al., 2008); 5, M. aurea DSM 18055 (Weon et al., 2008); 6, M. brevitalea DSM 18925 ${ }^{\mathrm{T}}$ (Zul et al., 2008; Weon et al., 2009); 7 , M. dura DSM $17513^{\mathrm{T}}$ (Weon et al., 2008); 8, M. lutea DSM 17473 ${ }^{\mathrm{T}}$ (Weon et al., 2008); 9, M. niabensis KACC 12632 ${ }^{\mathrm{T}}$ (Weon et al., 2009); 10, M. niastensis KACC $12599^{\mathrm{T}}$ (Weon et al., 2009); 11, M. plicata DSM $17505^{\mathrm{T}}$ (Weon et al., 2008); 12, M. timonae DSM 16850 ${ }^{\mathrm{T}}$ (Weon et al., 2008); 13, N. alkalitolerans KACC $12188^{\mathrm{T}}$ (data from this study); 14, N. haematophilus KACC $13771^{\mathrm{T}}$ (data from this study); $15, N$. varians KACC $13770^{\mathrm{T}}$ (data from this study). +, Positive; (+), weakly positive; - , negative.

\begin{tabular}{|c|c|c|c|c|c|c|c|c|c|c|c|c|c|c|c|}
\hline Characteristic & 1 & 2 & 3 & 4 & 5 & 6 & 7 & 8 & 9 & 10 & 11 & 12 & 13 & 14 & 15 \\
\hline Oxidase & + & + & + & $+{ }^{a_{\star}}$ & $(+)^{b}$ & $-{ }^{c}$ & $+{ }^{a}$ & $+{ }^{a}$ & + & + & $-{ }^{a}$ & $+{ }^{e}$ & $-{ }^{f}$ & $+^{g}$ & $+{ }^{g}$ \\
\hline Nitrate reduction & - & - & + & + & - & $+{ }^{c}$ & - & - & + & - & - & - & $-{ }^{f}$ & - & - \\
\hline Urease & - & - & + & - & - & $-^{d}$ & - & - & - & - & - & - & $+{ }^{f}$ & - & - \\
\hline $\begin{array}{l}\text { Hydrolysis of } \\
\text { aesculin }\end{array}$ & + & - & + & + & + & $+{ }^{d}$ & + & + & - & + & + & + & $+{ }^{f}$ & - & $(+)$ \\
\hline Assimilation of: & & & & & & & & & & & & & & & \\
\hline Adipic acid & - & + & - & + & + & $+{ }^{d}$ & - & + & - & - & - & - & - & + & - \\
\hline L-Alanine & - & + & + & + & + & - & + & - & - & + & + & + & + & - & + \\
\hline L-Arabinose & - & - & + & + & - & $-{ }^{d}$ & + & + & - & + & + & + & + & - & + \\
\hline D-Glucose & - & - & + & + & + & $+{ }^{d}$ & + & - & - & + & + & + & + & - & - \\
\hline Glycogen & + & + & + & + & + & - & + & - & - & - & + & + & - & + & + \\
\hline L-Histidine & - & + & + & - & - & - & - & - & - & - & - & + & + & - & - \\
\hline $\begin{array}{l}\text { 3-Hydroxy- } \\
\text { benzoic acid }\end{array}$ & - & - & - & - & - & - & - & - & - & + & - & - & + & + & - \\
\hline $\begin{array}{l}\text { 4-Hydroxy- } \\
\text { benzoic acid }\end{array}$ & - & - & - & + & - & - & + & - & - & + & - & - & - & + & - \\
\hline $\begin{array}{l}\text { 3-Hydroxy- } \\
\text { butyric acid }\end{array}$ & - & + & + & + & + & + & + & - & - & + & + & + & + & + & + \\
\hline Lactic acid & - & - & - & + & - & - & - & - & - & - & - & + & - & - & - \\
\hline $\begin{array}{l}\text { Potassium } \\
\text { gluconate }\end{array}$ & - & - & - & + & - & $-{ }^{d}$ & + & + & - & + & + & + & - & - & - \\
\hline L-Proline & - & + & + & + & + & + & + & + & - & + & + & + & + & - & + \\
\hline Propionic acid & - & + & + & - & $(+)$ & + & - & - & - & - & - & - & + & + & + \\
\hline L-Rhamnose & - & - & - & + & + & - & + & - & - & + & + & + & + & - & + \\
\hline L-Serine & - & + & + & + & + & - & - & - & - & - & + & + & + & - & + \\
\hline Suberic acid & - & + & - & - & + & + & - & - & - & - & - & - & - & + & - \\
\hline Trisodium citrate & - & - & - & - & + & $-{ }^{d}$ & - & - & - & - & - & + & + & - & - \\
\hline Valeric acid & - & + & - & - & - & + & - & - & - & - & - & - & - & + & - \\
\hline $\begin{array}{l}\text { DNA G + C content } \\
(\mathrm{mol} \%)\end{array}$ & 66.1 & 67.8 & 68.9 & $65.3^{a}$ & $66.0^{b}$ & 65.3 & $65.9^{a}$ & $63.3^{a}$ & 67.8 & 66.6 & $65.1^{a}$ & $62-67^{e}$ & $62.4 \pm 0.3^{f}$ & ND & $\mathrm{ND}$ \\
\hline
\end{tabular}

${ }^{\star}$ Data from: $a$, Zhang et al. (2006); b, Gallego et al. (2006); c, Zul et al. (2008); d, Weon et al. (2009); e, Lindquist et al. (2003); $f$, Xu et al. (2005); g, Kämpfer et al. (2008).

sources and the sources of isolation. According to phenotypic comparisons between many recently described members of the genera Naxibacter and Massilia, the abovementioned phenotypic properties are not genus-specific but can be variable among species of the two genera. Furthermore, phosphatidylinositol mannosides originally described as being present in members of the genus Naxibacter (Xu et al., 2005) were absent and phosphatidylethanolamine, phosphatidylglycerol and diphosphatidylglycerol were detected as the major polar lipids (Kämpfer et al., 2008). According to previously reported data, there were no unique genus-specific phenotypic characteristics that distinguished the genera Massilia and Naxibacter. In addition, the polar lipid profiles and fatty acids of both genera have not been found to show any significant differences. In the future, some genera, including the genera Massilia and Naxibacter and another closely related phylogenetic relative, the genus Telluria, will need further reclassification as more taxonomic data become available. At present, based on the polyphasic taxonomic approach described here, particularly on the basis of the phylogenetic evaluation, it is suggested that strains $5317 \mathrm{~J}-18^{\mathrm{T}}$ and $5414 \mathrm{~S}-25^{\mathrm{T}}$ should be classified as novel species of the genera Massilia and Naxibacter, for which the names Massilia jejuensis sp. nov. and Naxibacter suwonensis sp. nov. are proposed, respectively. 


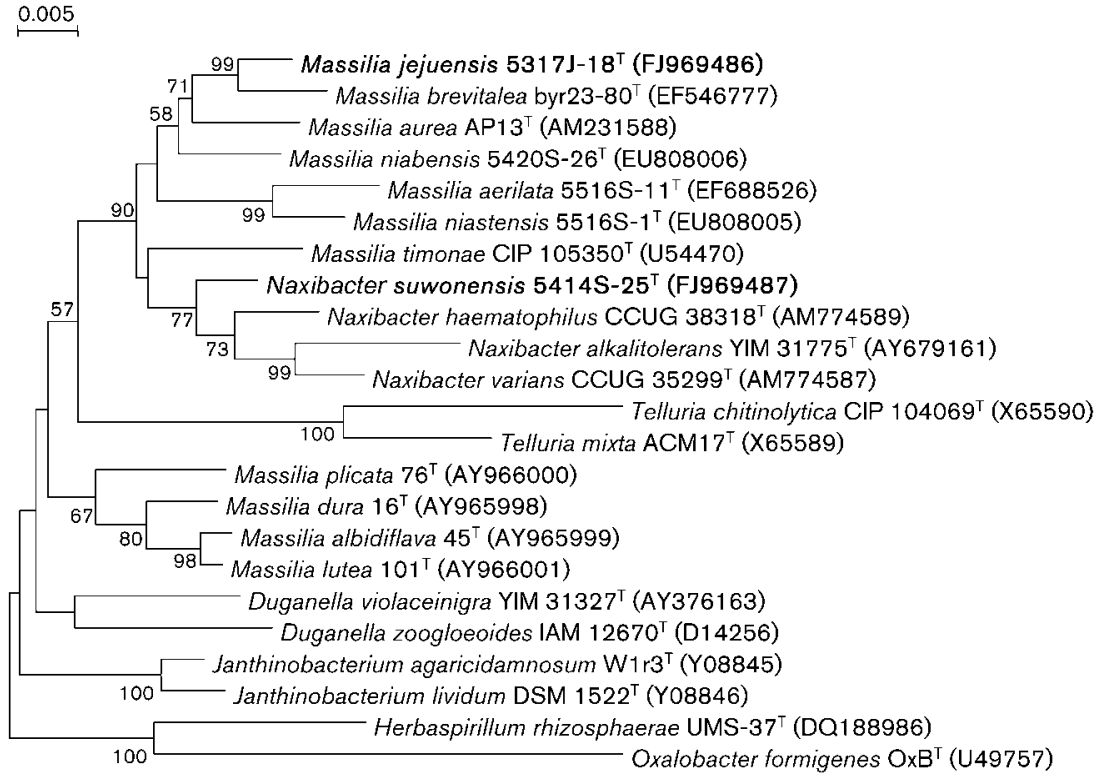

Fig. 1. Phylogenetic tree based on $16 \mathrm{~S}$ rRNA gene sequences. The positions of strains $5317 \mathrm{~J}-18^{\top}$ and $5414 \mathrm{~S}-25^{\top}$ are shown with respect to other closely related species. The tree was generated using the NJ method. Numbers at the nodes indicate bootstrap values, expressed as percentages of 1000 replications; only values $>50 \%$ are shown. Bar, 0.005 accumulated changes per nucleotide.

\section{Description of Massilia jejuensis sp. nov.}

Massilia jejuensis (je.ju.en'sis. N.L. masc. adj. jejuensis referring to Jeju Island, Republic of Korea, where the type strain was found).

Cells are aerobic, Gram-negative, motile with single flagellum, rod-shaped $(1.1-1.5 \times 1.3-3.0 \mu \mathrm{m})$. Catalase- and oxidasepositive. Colonies are light orange, round and convex with clear margins. Grows at $5-35{ }^{\circ} \mathrm{C}$ and $\mathrm{pH}$ 6.0-9.0; optimum growth occurs at $30{ }^{\circ} \mathrm{C}$ and $\mathrm{pH}$ 7.0. Does not require $\mathrm{NaCl}$ for growth, but can tolerate $1 \%(\mathrm{w} / \mathrm{v}) \mathrm{NaCl}$. Hydrolyses hypoxanthine and Tween 80 and weakly hydrolyses starch and tyrosine. Does not hydrolyse carboxymethylcellulose, casein, chitin, DNA, pectin or xanthine. Grows on R2A and nutrient agar (Difco), but not on tryptic soy agar (Difco) or MacConkey agar (Difco). According to API 20NE test strips, positive for aesculin hydrolysis, but negative for nitrate reduction, indole production, glucose fermentation,

Table 2. Cellular fatty acid contents (\%) of species of the genera Massilia and Naxibacter

Strains: $1,5317 \mathrm{~J}-18^{\mathrm{T}} ; 2,5414 \mathrm{~S}-25^{\mathrm{T}} ; 3$, M. aerilata KACC $12505^{\mathrm{T}} ; 4$, M. albidiflava DSM $17472^{\mathrm{T}} ; 5$, M. aurea DSM $18055^{\mathrm{T}}$; 6 , M. brevitalea DSM $18925^{\mathrm{T}}$; 7, M. dura DSM $17513^{\mathrm{T}}$; 8, M. lutea DSM $17473^{\mathrm{T}}$; 9, M. niabensis KACC $12632^{\mathrm{T}}$; 10, M. niastensis KACC $12599^{\mathrm{T}}$; 11 , M. plicata DSM $17505^{\mathrm{T}}$ (Zhang et al., 2006); 12, M. timonae DSM $16850^{\mathrm{T}}$; 13, N. alkalitolerans KACC $12188^{\mathrm{T}}$; 14, N. haematophilus KACC $13771^{\mathrm{T}}$; 15 , N. varians KACC $13770^{\mathrm{T}}$. Data for taxa 1-2 and 13-15 are from this study; data for taxa 3-10 and 12 are from Weon et al. (2009). -, <1\% or not detected.

\begin{tabular}{|c|c|c|c|c|c|c|c|c|c|c|c|c|c|c|c|}
\hline Fatty acid & 1 & 2 & 3 & 4 & 5 & 6 & 7 & 8 & 9 & 10 & 11 & 12 & 13 & 14 & 15 \\
\hline $\mathrm{C}_{10: 0} 3-\mathrm{OH}$ & 6.1 & 5.4 & 4.7 & 7.0 & 6.0 & 4.9 & 5.5 & 5.7 & 6.6 & 5.5 & 10.1 & 4.6 & 3.2 & 3.0 & 3.3 \\
\hline $\mathrm{C}_{12: 0}$ & 5.9 & 4.4 & 3.4 & 5.3 & 4.4 & 5.0 & 3.9 & 4.0 & 8.9 & 4.7 & 7.1 & 3.3 & 3.3 & 3.3 & 3.7 \\
\hline $\mathrm{C}_{12: 0} 2-\mathrm{OH}$ & 1.7 & 2.4 & - & - & - & 2.0 & - & - & - & 2.4 & 1.6 & 2.2 & 2.2 & 1.5 & 2.0 \\
\hline $\mathrm{C}_{14: 0}$ & - & 1.2 & 1.9 & 2.6 & 2.0 & - & 1.1 & 1.2 & - & - & - & - & - & - & - \\
\hline $\mathrm{C}_{14: 0} 2-\mathrm{OH}$ & - & - & 2.5 & 2.4 & 2.5 & - & 2.6 & 2.9 & - & - & 6.1 & - & - & - & - \\
\hline anteiso- $C_{15: 0}$ & - & - & - & - & - & - & - & - & - & - & - & - & - & 1.5 & - \\
\hline $\mathrm{C}_{16: 0}$ & 22.5 & 28.8 & 30.6 & 23.4 & 27.2 & 23.0 & 27.5 & 26.6 & 23.6 & 26.9 & 25.1 & 30.5 & 26.6 & 26.2 & 28.5 \\
\hline iso- $\mathrm{C}_{16: 0}$ & - & - & - & - & - & - & - & - & - & - & - & - & - & 2.1 & - \\
\hline $\mathrm{C}_{17: 0}$ cyclo & 1.0 & 2.9 & 6.1 & - & - & - & - & - & - & 3.4 & - & 3.7 & - & 2.7 & - \\
\hline iso- $\mathrm{C}_{17: 0}$ & - & - & - & - & - & - & - & - & - & - & - & - & - & 1.6 & - \\
\hline iso- $\mathrm{C}_{17: 1} \omega 9 c$ & - & - & - & - & - & - & - & - & - & - & - & - & - & 1.4 & - \\
\hline $\mathrm{C}_{18: 1} \omega 7 c$ & 12.1 & 7.8 & 11.7 & 7.4 & 7.9 & 9.0 & 7.03 & 7.8 & 7.8 & 12.3 & 11.7 & 7.9 & 6.6 & 8.7 & 8.1 \\
\hline$C_{20: 0}$ & - & - & - & - & - & - & - & - & - & 2.6 & - & - & - & - & - \\
\hline $\begin{array}{l}\text { Summed feature } \\
3^{\star}\end{array}$ & 49.0 & 45.8 & 35.2 & 46.0 & 48.6 & 54.2 & 52.0 & 51.1 & 46.0 & 38.1 & 36.9 & 47.0 & 55.2 & 44.7 & 51.7 \\
\hline
\end{tabular}

${ }^{\star}$ Summed feature 3 included $\mathrm{C}_{16: 1} \omega 7 c$ and/or iso- $\mathrm{C}_{15: 0} 2-\mathrm{OH}$. 
arginine hydrolysis, urease, gelatin hydrolysis and $\beta$ galactosidase. Assimilates glycogen, but does not assimilate any other substrates embedded in the API 20NE and API ID $32 \mathrm{GN}$ strips. Produces alkaline phosphatase, esterase (C4), esterase lipase (C8), leucine arylamidase, naphtholAS-BI-phosphohydrolase and $\alpha$-glucosidase, but a weak reaction for valine arylamidase and acid phosphatase. Does not produce lipase (C14), cystine arylamidase, trypsin, $\alpha$-chymotrypsin, $\alpha$-galactosidase, $\beta$-galactosidase, $\beta$-glucuronidase, $\beta$-glucosidase, $N$-acetyl- $\beta$-glucosaminidase, $\alpha$-mannosidase or $\alpha$-fucosidase (API ZYM test strip). The major polar lipids are phosphatidylethanolamine, phosphatidylglycerol and diphosphatidylglycerol. The major fatty acids are summed feature $3\left(\mathrm{C}_{16: 1} \omega 7 c\right.$ and/or iso- $\left.\mathrm{C}_{15: 0} 2-\mathrm{OH}\right)$ and $\mathrm{C}_{16: 0}$. Q-8 is the predominant respiratory quinone.

The type strain, 5317J-18 ${ }^{\mathrm{T}}\left(=\mathrm{KACC} 12634^{\mathrm{T}}=\mathrm{DSM} 21309^{\mathrm{T}}\right)$, was isolated from an air sample from Jeju island, Republic of Korea. The DNA $\mathrm{G}+\mathrm{C}$ content of the type strain is $66.1 \mathrm{~mol} \%$.

\section{Description of Naxibacter suwonensis sp. nov.}

Naxibacter suwonensis (su.won.en'sis. N.L. masc. adj. suwonensis referring to Suwon region, Republic of Korea, where the type strain was found).

Cells are aerobic, Gram-negative, motile with a single flagellum and rod-shaped $(0.6-0.8 \times 1.2-3.0 \mu \mathrm{m})$. Catalaseand oxidase-positive. Colonies are ivory coloured, round and convex with clear margins. Grows at $5-40{ }^{\circ} \mathrm{C}$ and pH 6.0-9.0; optimum growth occurs at $30{ }^{\circ} \mathrm{C}$ and pH 7.0. Does not require $\mathrm{NaCl}$ for growth, but can tolerate $1 \%$ $(\mathrm{w} / \mathrm{v}) \mathrm{NaCl}$. Hydrolyses casein, hypoxanthine, Tween 80 and tyrosine, hydrolyses xanthine weakly, but does not hydrolyse carboxymethylcellulose, chitin, DNA, pectin or starch. Grows on R2A, nutrient agar (Difco) and tryptic soy agar (Difco), but not on MacConkey agar (Difco). According to API 20NE test strips, positive reaction for gelatin hydrolysis, but negative result for nitrate reduction, indole production, glucose fermentation, arginine hydrolysis, urease, aesculin hydrolysis and $\beta$-galactosidase. Assimilates maltose, adipic acid, malic acid, phenylacetic acid, suberic acid, L-alanine, glycogen, L-serine, propionic acid, valeric acid, L-histidine, 3-hydroxybutyric acid and L-proline, but does not assimilate D-glucose, L-arabinose, D-mannose, D-mannitol, $\mathrm{N}$-acetylglucosamine, potassium gluconate, capric acid, trisodium citrate, L-rhamnose, D-ribose, inositol, sucrose, itaconic acid, sodium malonate, sodium acetate, lactic acid, potassium 5-ketogluconate, 3-hydroxybenzoic acid, salicin, melibiose, L-fucose, D-sorbitol, potassium 2-ketogluconate or 4-hydroxybenzoic acid. Produces alkaline phosphatase, esterase lipase (C8), leucine arylamidase, valine arylamidase, acid phosphatase, naphthol-AS-BI-phosphohydrolase, $\alpha$-glucosidase. Weak reaction for esterase (C4) and cystine arylamidase, but negative reaction for lipase (C14), trypsin, $\alpha$-chymotrypsin, $\alpha$-galactosidase, $\beta$-galactosidase, $\beta$-glucuronidase, $\beta$-glucosidase, $N$-acetyl- $\beta$-glucosaminidase, $\alpha$-man- nosidase and $\alpha$-fucosidase. The major polar lipids are phosphatidylethanolamine, phosphatidylglycerol and diphosphatidylglycerol. The major fatty acids are summed feature 3 $\left(\mathrm{C}_{16: 1} \omega 7 c\right.$ and/or iso- $\left.\mathrm{C}_{15: 0} 2-\mathrm{OH}\right)$ and $\mathrm{C}_{16: 0}$. Q-8 is the predominant respiratory quinone.

The type strain, $5414 \mathrm{~S}-25^{\mathrm{T}}\left(=\right.$ KACC $12635^{\mathrm{T}}=$ DSM $\left.21311^{\mathrm{T}}\right)$, was isolated from an air sample from the Suwon region, Republic of Korea. The DNA G + C content of the type strain is $67.8 \mathrm{~mol} \%$.

\section{Acknowledgements}

This work was supported by National Academy of Agricultural Science (NAAS), Rural Development Administration, Republic of Korea.

\section{References}

Ausubel, F. M., Brent, R., Kingston, R. E., Moore, D. D., Seidman, J. G., Smith, J. A. \& Struhl, K. (editors) (1987). Current Protocols in Molecular Biology. New York: Greene/Wiley Interscience.

Chun, J., Lee, J. H., Jung, Y., Kim, M., Kim, S., Kim, B. K. \& Lim, Y. W. (2007). EzTaxon: a web-based tool for the identification of prokaryotes based on $16 \mathrm{~S}$ ribosomal RNA gene sequences. Int J Syst Evol Microbiol 57, 2259-2261.

Felsenstein, J. (1981). Evolutionary trees from DNA sequences: a maximum likelihood approach. J Mol Evol 17, 368-376.

Felsenstein, J. (1985). Confidence limits on phylogenies: an approach using the bootstrap. Evolution 39, 783-791.

Gallego, V., Sánchez-Porro, C., García, M. T. \& Ventosa, A. (2006). Massilia aurea sp. nov., isolated from drinking water. Int J Syst Evol Microbiol 56, 2449-2453.

Kämpfer, P., Falsen, E. \& Busse, H. J. (2008). Naxibacter varians sp. nov. and Naxibacter haematophilus sp. nov., and emended description of the genus Naxibacter. Int J Syst Evol Microbiol 58, 1680-1684.

Kluge, A. G. \& Farris, J. S. (1969). Quantitative phyletics and the evolution of anurans. Syst Zool 18, 1-32.

Kumar, S., Tamura, K. \& Nei, M. (2004). MEGA3: Integrated software for molecular evolutionary genetics analysis and sequence alignment. Brief Bioinform 5, 150-163.

La Scola, B., Birtles, R. J., Mallet, M. N. \& Raoult, D. (1998). Massilia timonae gen. nov., sp. nov., isolated from blood of an immunocompromised patient with cerebellar lesions. J Clin Microbiol 36, 28472852.

Lindquist, D., Murrill, D., Burran, W. P., Winans, G., Janda, J. M. \& Probert, W. (2003). Characteristics of Massilia timonae and Massilia timonae-like isolates from human patients, with an emended description of the species. J Clin Microbiol 41, 192-196.

Mesbah, M., Premachandran, U. \& Whitman, W. B. (1989). Precise measurement of the $\mathrm{G}+\mathrm{C}$ content of deoxyribonucleic acid by highperformance liquid chromatography. Int J Syst Bacteriol 39, 159167.

Minnikin, D. E., O'Donnell, A. G., Goodfellow, M., Alderson, G., Athalye, M., Schaal, A. \& Parlett, J. H. (1984). An integrated procedure for the extraction of bacterial isoprenoid quinones and polar lipids. J Microbiol Methods 2, 233-241.

Saitou, N. \& Nei, M. (1987). The neighbor-joining method: a new method for reconstructing phylogenetic trees. Mol Biol Evol 4, 406425. 
Sasser, M. (1990). Identification of bacteria by gas chromatography of cellular fatty acids. Newark, DE: MIDI Inc.

Seldin, L. \& Dubnau, D. (1985). Deoxyribonucleic acid homology among Bacillus polymyxa, Bacillus macerans, Bacillus azotofixans, and other nitrogen-fixing Bacillus strains. Int J Syst Bacteriol 35, 151154.

Smibert, R. M. \& Krieg, N. R. (1994). Phenotypic characterization. In Methods for General and Molecular Bacteriology, pp. 607-654. Edited by P. Gerhardt, R. G. E. Murray, W. A. Wood \& N. R. Krieg. Washington, DC: American Society for Microbiology.

Thompson, J. D., Higgins, D. G. \& Gibson, T. J. (1994). CLUSTAL W: Improving the sensitivity of progressive multiple sequence alignment through sequence weighting, position-specific gap penalties and weight matrix choice. Nucleic Acids Res 22, 46734680 .

Wayne, L. G., Brenner, D. J., Colwell, R. R., Grimont, P. A. D., Kandler, O., Krichevsky, M. I., Moore, L. H., Moore, W. E. C., Murray, R. G. E. \& other authors (1987). International Committee on Systematic Bacteriology. Report of the ad hoc committee on reconciliation of approaches to bacterial systematics. Int J Syst Bacteriol 37, 463464.
Weisburg, W. G., Barns, S. M., Pelletier, D. A. \& Lane, D. J. (1991). 16 S ribosomal DNA amplification for phylogenetic study. J Bacteriol 173, 697-703.

Weon, H. Y., Kim, B. Y., Son, J. A., Jang, H. B., Hong, S. K., Go, S. J. \& Kwon, S. W. (2008). Massilia aerilata sp. nov., isolated from an air sample. Int J Syst Evol Microbiol 58, 1422-1425.

Weon, H. Y., Kim, B. Y., Hong, S. B., Jeon, Y. A., Koo, B. S., Kwon, S. W. \& Stackebrandt, E. (2009). Massilia niabense sp. nov. and Massilia niastense sp. nov., isolated from air samples. Int J Syst Evol Microbiol 59, 1656-1660.

Xu, P., Li, W. J., Tang, S. K., Zhang, Y. Q., Chen, G.-Z., Chen, H.-H., Xu, L. H. \& Jiang, C. L. (2005). Naxibacter alkalitolerans gen. nov., sp. nov., a novel member of the family 'Oxalobacteraceae' isolated from China. Int J Syst Evol Microbiol 55, 1149-1153.

Zhang, Y.-Q., Li, W.-J., Zhang, K.-Y., Tian, X.-P., Jiang, Y., Xu, L.-H., Jiang, C.-L. \& Lai, R. (2006). Massilia dura sp. nov., Massilia albidiflava sp. nov., Massilia plicata sp. nov. and Massilia lutea sp. nov., isolated from soils in China. Int J Syst Evol Microbiol 56, 459-463.

Zul, D., Wanner, G. \& Overmann, J. (2008). Massilia brevitalea sp. nov., a novel betaproteobacterium isolated from lysimeter soil. Int $J$ Syst Evol Microbiol 58, 1245-1251. 